\title{
O quarto paradigma da imagem e sua aplicação prática na divulgação da moda
}

\section{The fourth imagery paradigm and its practical application on fashion propaganda}

GOMES, Rogério Zanetti

Universidade Estadual de Londrina - UEL | rogerioghomes@gmail.com

ROBERTO, Carolina Mendes Pereira

Universidade Estadual de Londrina - UEL | caru.mendes@hotmail.com

\begin{abstract}
Resumo
O artigo relaciona o processo de divulgação da Abstract

Moda com as teorias da imagem de Santaella e Nöth pelo percurso do tempo. Analisa como a Moda é informada por meio de ilustrações, texto, fotografias, revistas e mídias sociais digitais. Faz a distinção entre os três paradigmas da imagem e aplica o quarto paradigma aos meios de comunicação de Moda por meio do Design Editorial e da programação visual.

This paper relates the process of Fashion propaganda with the various Santaella and Nöth's theories on imagery. We analyze how Fashion communicates through illustrations, text, photographs, magazines and digital social media. We distinguish between the three imagery paradigms and apply the fourth paradigm to the fashion media through Editorial Design and visual programming.
\end{abstract}

Palavras-chave: Imagem. Fotografia. História da moda. Revista de moda.

Keywords: Image. Photography. Fashion history. Fashion magazine. 


\section{INTRODUC̣ÃO}

Em um mundo onde as imagens digitais estão cada vez mais presentes no cotidiano das pessoas, as reflexões acerca de sua influência tornaram-se inevitáveis. Grandes revistas de Moda estão sentindo a queda na venda dos periódicos impressos e consequentemente mudando o foco de seu trabalho para as plataformas digitais. Perceberam que grande parte de seu público está diariamente visitando as mídias sociais digitais, sites e aplicativos com conteúdo de acesso livre, além de ter aprendido a absorver informações através de imagens conceituais. "O embate impresso versus digital acabou e, agora, fazemos parte de uma nova era de ouro do design de revistas, um ecossistema de mídia impressa integrada com redes sociais, eventos, campanhas e produtos de mídia móvel." (CADWELL; ZAPATERRA, 2014, p. 7).

É comum os usuários acompanharem diversas marcas, revistas online, sites de notícias e celebridades pelos aplicativos, o que acaba por deixá-los confusos e cansados em receber tanta informação e publicidade que não Ihes interessam, além de ser complicado arquivar as publicações mais interessantes. Desta forma, o excesso de publicações online faz com que conteúdos direcionados sejam cada vez mais procurados pelos internautas.

Neste contexto, este trabalho relaciona os três paradigmas da imagem de Lucia Santaella e Winfried Nöth e o quarto paradigma da imagem de Santaella com o processo de divulgação da Moda desde o seu início até os dias de hoje. Os autores analisam as maneiras pelas quais a informação é veiculada desde a pré-história e fazem um panorama de como ela será futuramente a partir da criação de uma revista social digital de compartilhamento de conteúdo de Moda, a Miamag.

Caldwell e Zapaterra (2014) afirmam que o design editorial para material impresso e digital é um laboratório de pesquisa emocionante e em constante evolução, e uma plataforma de lançamento para as inovações estilísticas que são, muitas vezes, adotadas com entusiasmo por outras áreas da comunicação visual. Por esta razão surge a necessidade da criação de um novo meio de comunicação de Moda.

Definiu-se o seguinte problema a ser resolvido: “De que forma o quarto paradigma da imagem pode ser aplicado na divulgação da informação de Moda?". As metas são divulgar de forma personalizada informação de Moda, possibilitar publicidade direcionada e permitir a geração e arquivamento de conteúdo. Os requerimentos necessários para cumprir as necessidades do trabalho são integrar mídias sociais digitais no cadastramento de usuários e pesquisar referências de sites e aplicativos que viabilizam a organização das publicações. 


\section{O PRIMEIRO PARADIGMA}

No livro O Mundo Codificado, Vilém Flusser explica três configurações de imagem (pré-histórica, histórica e pós-histórica) com base na evolução de seu processo produtivo. Porém, os autores Lucia Santaella e Winfred Nöth (1997) fazem um panorama sobre estas configurações através de quesitos como meio de produção, consequências dos meios de produção da imagem, as gradações das mudanças e as misturas entre os paradigmas. Para este trabalho, optou-se por utilizar as teorias de Santaella e Nöth para contextualizar cada paradigma da imagem, que são definidos paralelamente como pré-fotográfico, fotográfico e pós-fotográfico.

De acordo com Santaella e Nöth (1997), o paradigma pré-fotográfico nomeia todas as imagens que são produzidas artesanalmente, ou seja, imagens feitas manualmente, dependendo da habilidade de um indivíduo para tornar a imaginação visual, o invisível e também o visível em figuras bi ou tridimensionais. Depende também de uma matéria para existir, seja por instrumentos, suportes, superfícies e substâncias utilizadas na sua realização. O seu produtor é um artista e depende de seu olhar e imaginação para tornarse visível. "O que resulta disso não é só uma imagem, mas um objeto único, autêntico, solene e carregado de sacralidade [...] daquele instante santo e raro no qual o pintor pousou seu olhar sobre o mundo, dando forma a esse olhar num gesto irrepetível." (SANTAELLA; NÖTH, 1997, p. 164).

Está sujeito às erosões do tempo, pois o seu meio de armazenamento é matérico e perecível. $O$ artista, o objeto e a matéria tornam-se indissociáveis. Encontram-se estas imagens únicas em templos, galerias, museus e em sítios arqueológicos para a sua conservação e manutenção, o que acaba por depender do deslocamento dos apreciadores para contemplação. Santaella e Nöth (1997) ainda afirmam que o universo pré-fotográfico é caracterizado pela nostalgia, pela aura e pelo repouso.

O mundo pré-fotográfico da divulgação da imagem da Moda é iniciado entre os anos 1755 e 1793. Grandes costureiros na França confeccionavam miniaturas dos vestidos mais populares da época, e principalmente aqueles usados pelas pessoas mais importantes, como Maria Antonieta, também conhecida como a "Rainha da Moda". Estes costureiros levavam consigo a representação das roupas utilizadas pela francesa por toda a Europa. Costuravam em escala reduzida os modelos com os mesmos tecidos, aviamentos e acabamentos, e vestiam pequenas bonecas. Era uma forma de ilustrar materialmente os conceitos de vestimentas usadas pelas pessoas mais importantes da época.

Ao mesmo tempo apareceram os Costume Plates, simples ilustrações das roupas mais desejadas. Eram imagens de registro do que fora Moda

Projética, Londrina, v.10, n.3, p. 175-196, jul./dez. 2019 
em um determinado tempo. Entre os anos 1770 e 1889 a revista inglesa The Lady's Magazine se populariza por publicar os primeiros Fashion Plates, que diferentemente dos Costume Plates, agora mostra ilustrações do vestuário previsto para as próximas coleções dos costureiros. Este começo da divulgação da Moda é caracterizado pelo primeiro paradigma da imagem, pois dependia da habilidade manual do artista que a retratava, seja ela por meio da costura ou da ilustração. A imagem era contemplativa e carregada de percepções dos artistas que as retratavam.

Figura 1 - Fashions for March, edição de fevereiro de 1818, The Lady's Magazine.

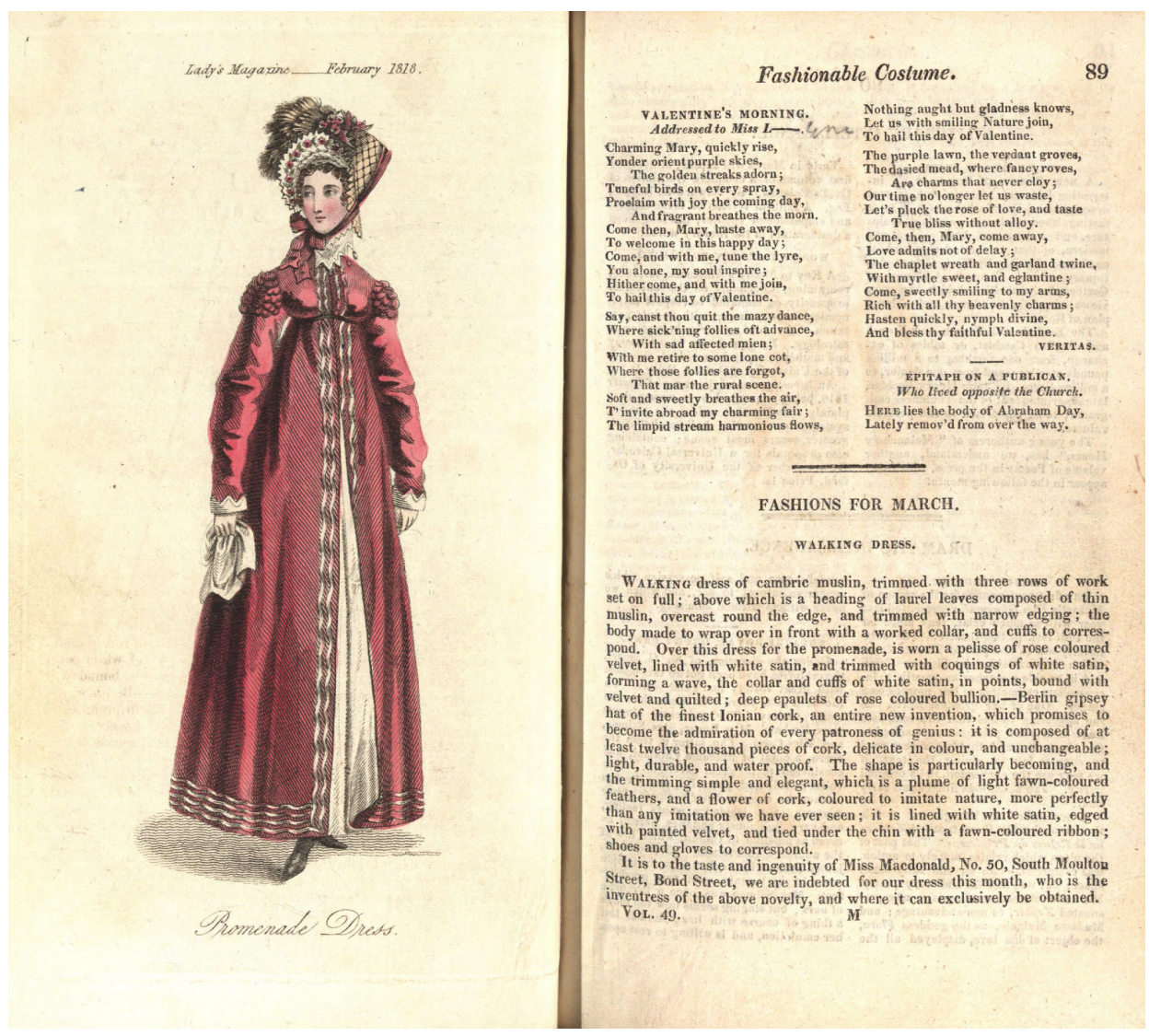

Fonte: Batchelor (2016).

Paralelamente aos Fashion Plates, nos Estados Unidos a primeira revista de Moda feminina é lançada no ano de 1867. A Harper's Bazaar unia ilustrações e textos em suas publicações, informando às leitoras não somente formas, mas também conceitos sobre a Moda. Não muito tempo depois, em 1892, a revista Vogue entra no mercado americano.

\section{SEGUNDO PARADIGMA}

O início da passagem gradativa do primeiro para o segundo paradigma dá-se através de técnicas da câmara escura e de perspectiva artificial do Quattrocento, pois já dispunha de características óticas da fotografia, afirmam 
Figura 2 - Primeira edição da Harper's Bazaar, 1867.

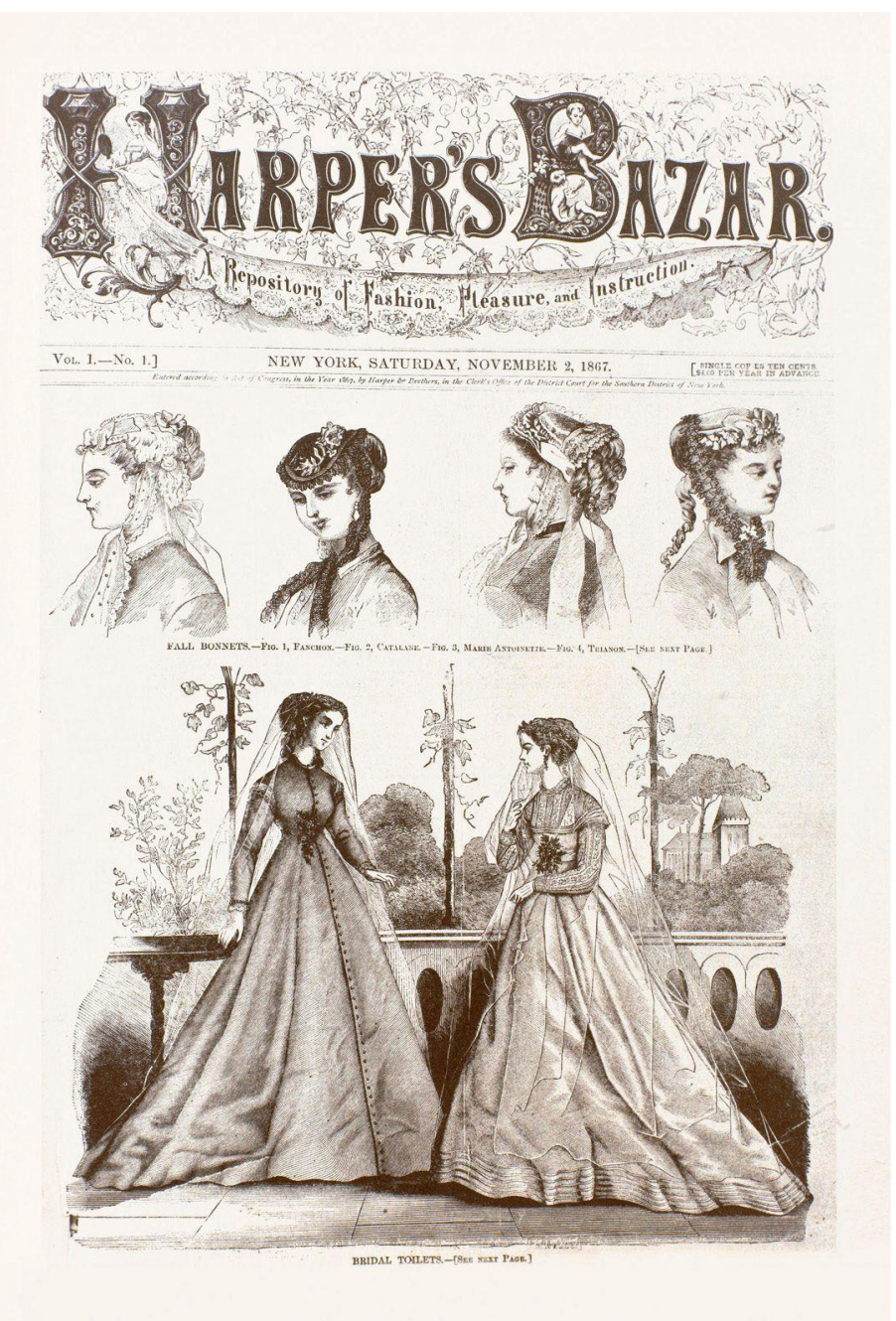

Fonte: Mooalem (2017).

Santaella e Nöth (1997). Da mesma forma, dependia de um meio de produção que fosse reprodutível, fixando o desenho que a luz deixava na parede interna da câmera escura. A descoberta das propriedades fotoquímicas dos sais de prata no Renascimento dispensou a mediação artística no processo de obtenção da imagem, mas ainda dependia da captação de um objeto real para a produção.

“Nesse paradigma, a imagem é o resultado do registro sobre um suporte químico ou eletromagnético (cristais de prata da foto ou a modulação eletrônica do vídeo) do impacto dos raios luminosos emitidos pelo objeto ao passar pela objetiva." (SANTAELLA; NÖTH, 1997, p. 165). Depende também do negativo para a reprodução dos fragmentos do mundo visível e da visão do sujeito que focaliza o seu olhar no modelo físico que decide eternizar, fragmentando a realidade sob um certo ponto de vista. É um processo diádico pois depende de um objeto real e do sujeito com capacidade perceptiva que o retrata por meio da colisão ótica.

A fotografia é passível de reprodução pois os negativos e as fitas magnéticas podem ser copiados, revelados e reproduzidos a qualquer momento, 
porém estes estão sujeitos à deterioração com o passar do tempo, concluem Santaella e Nöth (1997). Estão presentes na era da comunicação em massa e podem ser encontradas em jornais, revistas, outdoors e telas. São também imagens do cinema, TV, vídeo e da holografia. O receptor da imagem fotográfica a observa e a identifica, procurando entender a conexão entre o real e as ações de quem a capturou, em um processo de confronto entre o sujeito e o mundo.

A passagem do primeiro para o segundo paradigma na divulgação da Moda teve sua importância quando as fotografias tornaram-se essenciais na comunicação das revistas, mesmo que ainda fossem em preto e branco. A partir de 1900 o desfile teve seu início na Maison Lucile, de Lucy Duff-Gordon. A estilista organizava eventos para mulheres da alta sociedade e celebridades, treinando modelos para desfilarem para a audiência. As leitoras passaram a se interessar pelos registros fotográficos dos desfiles e dessa forma poderiam vestir-se como as clientes dos grandes ateliers. Entre os anos 1913 e 1921, o fotógrafo responsável pela produção fotográfica da Vogue americana foi o alemão Adolph Meyer, considerado hoje o primeiro fotógrafo de Moda do mundo. A primeira fotografia colorida em uma revista de Moda foi da edição de 1932 da Vogue dos Estados Unidos, feita por Edward Steichen.

Figura 3 - Vogue USA, setembro de 1920, Adolph Meyer.

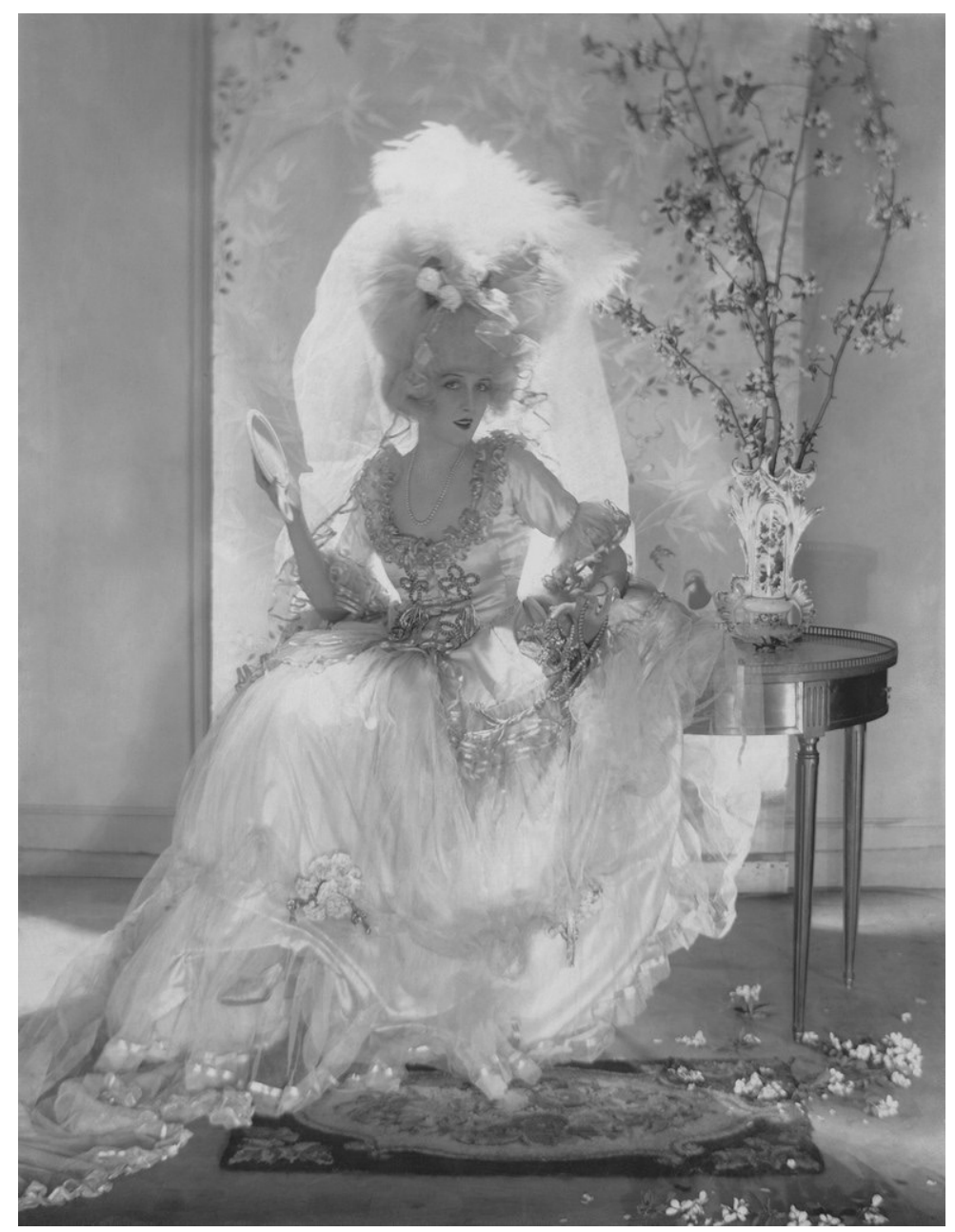

Fonte: Yaeger (2015). 
Até o início da década de 1970 as revistas restringiam a cor a capas e algumas reportagens, o restante era em preto e branco. Segundo Caldwell e Zapaterra (2014), à medida que a tecnologia de impressão avançava ao longo da década, a impressão colorida em impressoras de quatro cores tornou-se mais barata e o uso da cor disseminou-se. Também passou-se a imprimir em diferentes tamanhos, formatos e em papéis couchê.

Figura 4 - Capa revista Vogue USA, julho de 1932.

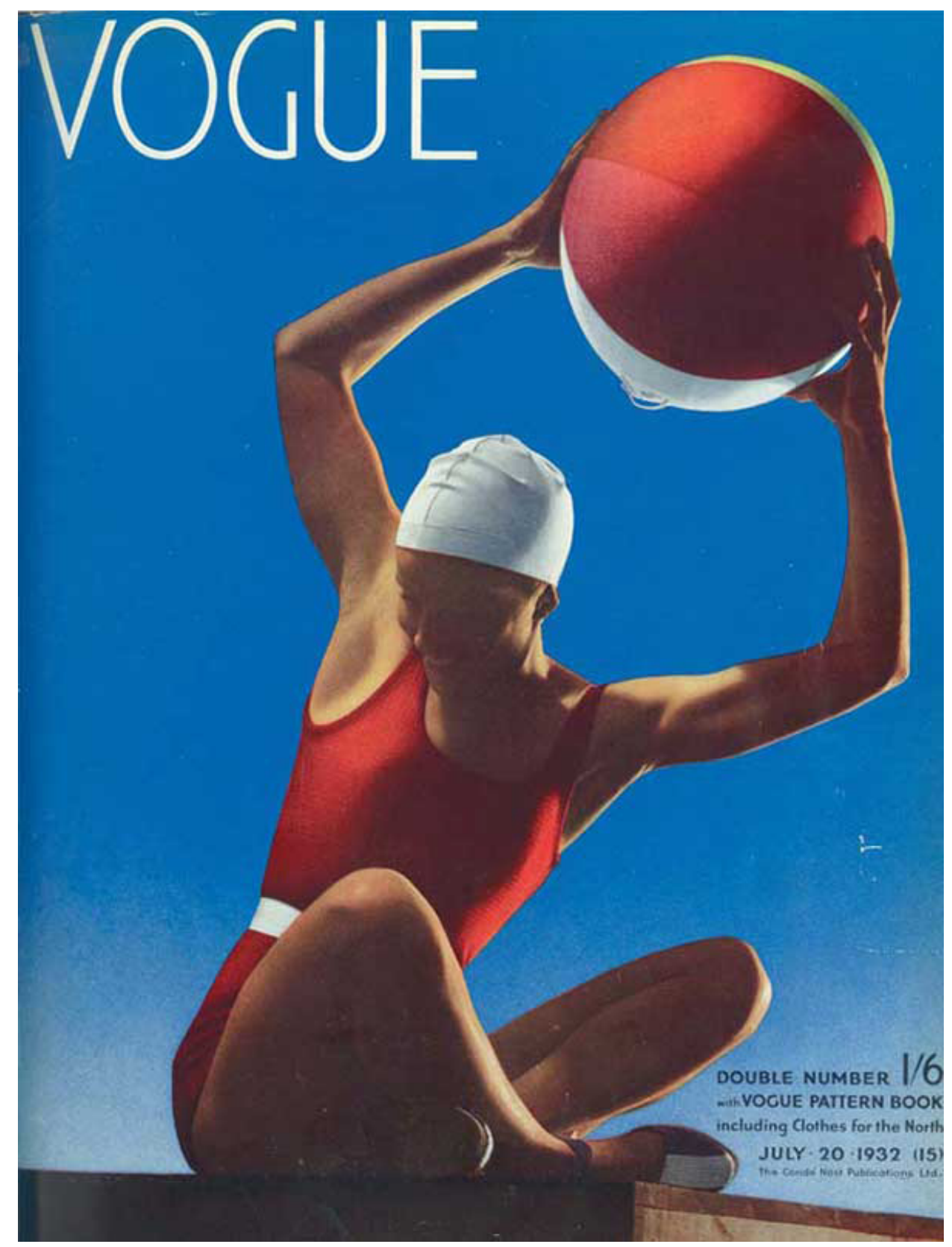

Fonte: Miranda (2012).

Entre os anos 1980 e 1990 os bens de luxo pareciam chegar com mais facilidade ao público. Com o grande investimento de anunciantes nas revistas e o aumento de novos estilistas, as publicações produziram edições volumosas e a imagem de Moda tornou-se mais democrática e acessível para as pessoas comuns. De acordo com Caldwell e Zapaterra (2014) as revistas estavam 
desfrutando de uma idade do ouro de colaborações inspiradas e um respeito pelas habilidades especializadas do design editorial e do jornalismo visual.

Figura 5 - Capa da Vogue UK, janeiro de 1987.

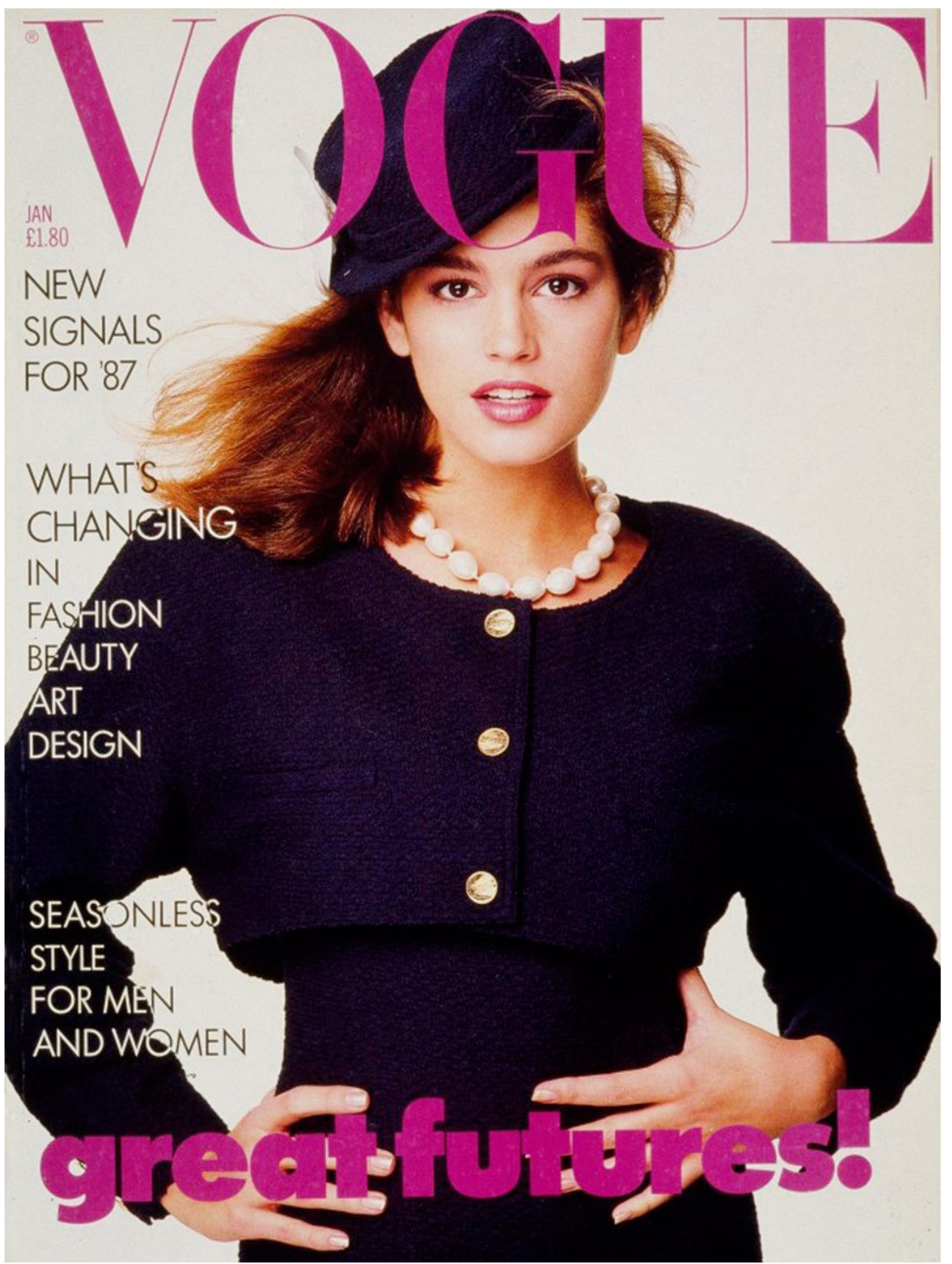

Fonte: Hutchings (2009).

A partir de 1990 as revistas passaram a reduzir os custos de produção. Caldwell e Zapaterra (2014) afirmam que as publicações deixaram de usar celebridades nas capas, os editores introduziram novas matérias e assuntos para tentar aumentar o seu número de leitores, as prensas antigas foram abandonadas e as provas de cor foram facilitadas com o advento da impressão digital. A tecnologia neste momento estava facilitando o processo de edição das revistas, mas o que viria em seguida já começava a assustar os editores. 
Já em 2010 a internet tornou-se uma grande ameaça e os profissionais da área foram obrigados a se adaptar às novas mídias digitais, para que o conteúdo fosse encaminhado de forma mais prática aos seus leitores. Da mesma forma, os anunciantes passaram a repensar em como atingiriam o seu público nas novas plataformas.

\section{TERCEIRO PARADIGMA}

A passagem da imagem fotográfica para a pós-fotográfica aconteceu na arte moderna, dos impressionistas a Mondrian e Pollock, onde a imagem tornou-se independente de objetos do mundo real, afirmam Santaella e Nöth (1997). Não se representava somente as formas fundamentais, mas a expressão conceitual, abstrata e icônica. A partir de 1950 os processos artísticos passaram entrelaçar diversas técnicas, meios, efeitos e tipos de criação, principalmente os pictóricos e fotográficos, também representado pela hibridização das artes. Aparece a partir daqui as formas sensoriais essenciais e a independência do visível, a arte visual deu lugar à conceitual.

De acordo com Santaella e Nöth (1997), terceiro paradigma referese às imagens sintéticas, simuladas ou infográficas, geradas por processos matemáticos e informáticos, computação e transmitidos por meio de uma tela de vídeo. O seu suporte virtual e simulado pode ser computadores e programas, os quais operam sobre um substrato simbólico, a informação. Sua representação é mais complexa por ser a transformação de uma matriz algorítmica em pixels. "Trata-se de uma imagem matriz, resultante da atribuição das propriedades e capacidades de um modelo e cujo substrato simbólico lhe dá o poder de funcionar como imagem-experimento, antecipando-se ao mundo para melhor controlá-lo." (SANTAELLA; NÖTH, 1997, p. 171).

O agente da imagem é um programador capaz de transformar valores numéricos em pontos elementares, resultando então em formas visuais interativas em uma tela. O seu meio de armazenamento é a memória do computador, o que a caracteriza como disponível e praticamente independente das restrições do tempo e do espaço.

Flusser (1985) afirma que a imagem técnica, ou pós-fotográfica, é aquela produzida por aparelhos. Ela é a codificação de um texto científico aplicado em uma superfície plana. Seu objetivo é disponibilizar um código universal para reunificar as linguagens. Com a evolução de instrumentos de comunicação e de armazenamento de dados, acredita-se que estará cada vez mais presente no cotidiano, simplificando os textos em imagens visuais. Diferentemente da pré-histórica, onde as informações eram passadas em forma de símbolos, e da histórica, onde estas são configuradas em linhas, a pós-história codificará 
textos em imagens e serão decifradas por quem deseja absorver os seus significados. Esta será a evolução da leitura virtual e imersiva, onde a escrita será inteiramente substituída por imagens técnicas.

De acordo com Caldwell e Zapaterra (2014), as primeiras publicações digitais de Moda eram principalmente sites com páginas em PDF que podiam ser movimentadas como se viram as páginas de um jornal ou revista convencional. A editora americana Condé Nast construiu seu próprio software personalizado e produziu a Wired, GQ e Vanity Fair, sem depender de sistemas de software externos. A chegada do HTML na década de 1990 como uma linguagem de codificação de computador permitiu que os designers incorporassem um conteúdo animado na Web. O navegador lê as tags e apresenta esse código como imagens e texto. "As revistas online projetadas para serem lidas em IPad ou um dispositivo móvel se tornaram altamente interativas; a forma como o usuário navega pela tela tem de ser cuidadosamente planejada para que ele queira interagir e aprofundar-se na publicação." (CALDWELL; ZAPATERRA, 2014, p. 164)

Paralelamente à disponibilidade de reportagens nos sites das revistas, nos anos 2000 apareceram os blogues que permitiam ao usuário seu próprio meio de comunicação, da mesma forma com o surgimento das mídias sociais digitais. A pessoa passou a não ser somente receptor de informações, mas também emissor e comunicador. O que são conhecidos por blogueiros, ou influenciadores digitais, nunca tiveram tanto espaço na internet. Em cada página do blog o usuário é capaz de enviar textos e fotografias sobre determinados assuntos, além de na maioria das vezes serem pagos para emitir mensagens relativas a um produto ou uma marca.

A principal diferença entre o passado e o presente é que o design inspiracional agora pode ser compartilhado com mais facilidade. Hoje, temos acesso rápido e confiável a uma vasta gama de imagens que existem na nuvem digital. Mais importante ainda, os designers continuam a usar as mídias sociais, como Twitter, Facebook e blogs, como uma ferramenta de compartilhamento, dando a todos a oportunidade de aprender com profissionais altamente qualificados. (CALDWELL; ZAPATERRA, 2014, p. 206).

O Instagram é uma mídia social digital desenvolvida em 2010 com o objetivo de compartilhar fotografias com filtros similares aos das câmeras Polaroid. Fez tanto sucesso que diversas revistas de Moda passaram a publicar conteúdo em formato de uma fotografia quadrada e uma breve texto como legenda. Muitos usuários do Instagram reduziram suas visitas aos sites das revistas, pois na nova plataforma é possível entender as últimas tendências através das imagens conceituais. As fotografias digitais passam por um processo de edição que muitas vezes dispensa o acompanhamento de palavras para a interpretação. 
Figura 6 - Tela inicial do site da Vogue US.

$\equiv$ VOGLE

\section{Fashion}

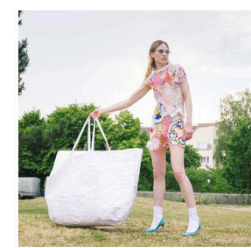

French Designer Lou de Bèroly Will Crochet Anything, Even Shoo FASHION

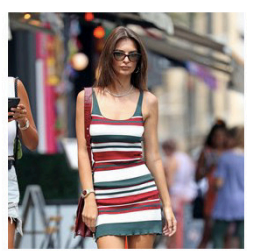

Put Away Your Sandals: Why Sneakers and Dresses Are Summers

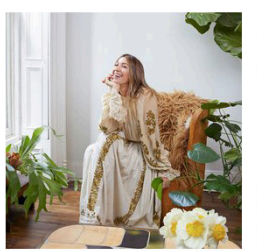

How Ulla Johnson Merges Fashion and Fantasy-On and Off the

Runway

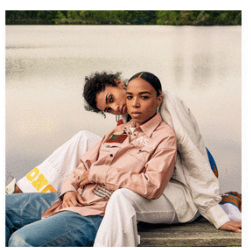

Fonte: Fashion (2018).

Figura 7 - Fotografias do Instagram da Vogue US.
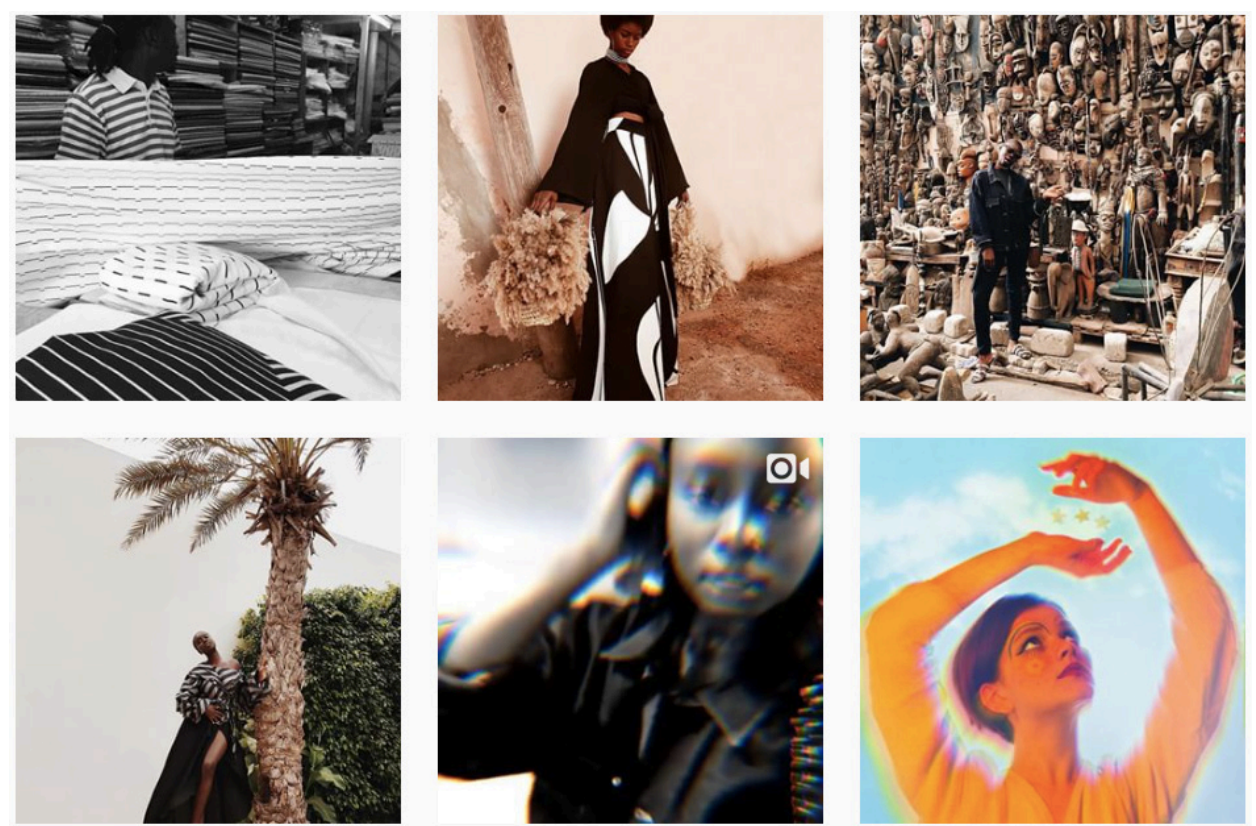

Fonte: Vogue (2018)

\section{QUARTO PARADIGMA APLICADO NA DIVULGAC̣ÃO DA MODA}

De acordo com Santaella (2013), o quarto paradigma da imagem é a tendência das misturas entre os outros paradigmas, é o hibridismo radical que as mídias e linguagens contemporâneas apresentam. É consequência do terceiro paradigma pois fotos podem misturar-se com outras formas visuais, sejam elas desenhos, imagens bi ou tridimensionais, diagramas e infográficos. $\mathrm{O}$ computador não só produz imagens e textos e armazena arquivos, mas permite a edição de outros formatos e o compartilhamento de dados multimídia por interfaces gráficas. A rede digital possibilita a livre distribuição das mídias, contribuindo para uma democratização do acesso à informação e a captação de conceitos através de imagens abstratas. 
Ilustração dessas misturas pode ser encontrada nos fenômenos artísticos que receberam o nome de hibridização das artes e contemporaneamente comparecem de modo mais cabal nas instalações, onde objetos, imagens artesanalmente produzidas, esculturas, fotos, filmes, vídeos, imagens sintéticas são misturados numa arquitetura, com dimensões, por vezes, até mesmo urbanísticas, responsável pela criação de paisagens sígnicas que instauram uma nova ordem perceptiva e vivencial em ambientes imaginativos e críticos capazes de regenerar a sensibilidade do receptor para o mundo em que vive (SANTAELLA; NÖTH, 1997, p. 183).

Na esfera do Design Editorial de Moda, a revista impressa agora é apenas um dentre os membros de uma família de produtos, afirmam Caldwell e Zapaterra (2014). No dia seis de agosto de 2018 a Editora Abril, que detinha os direitos de licenciamento da ELLE no Brasil comunicou o encerramento das atividades da revista impressa e digital. Sua publicação começou em 1988, e foram trinta anos a tentar se posicionar no mercado brasileiro. Mesmo com a versão online e estando presente em todas as mídias sociais digitais, não conseguiu dar continuidade à distribuição. É nesse cenário que podem surgir outras formas de se compartilhar conteúdo, entendendo que as pessoas já não se interessam somente em receber informação, mas também compartilhar suas próprias experiências.

Existem algumas plataformas recentes que auxiliam no entendimento de como será a comunicação futuramente. As revistas sociais são bons exemplos que reúnem conteúdo de outros fornecedores de notícias em um só perfil. De acordo com Caldwell e Zapaterra (2014), são uma combinação híbrida de um produto de marca bem editado e um feed de conteúdo agregado, e incentivam o usuário a "compartilhar", de uma maneira parecida com o antigo costume de arrancar páginas de revistas impressas para mostrar aos amigos. O histórico de buscas e as informações do usuário são essenciais para direcionar outros artigos de outros autores que lhe agradem e que esteja de acordo com as suas preferências individuais. Resumindo, monta-se a própria revista com matérias de diversas plataformas.

Segundo Caldwell e Zapaterra (2014) as publicações digitais estão se desenvolvendo rapidamente e fornecendo novas oportunidades para designers editoriais, editoras e anunciantes. A nova família digital consiste em sites, celulares, tablets Android e IPad. Os "aplicativos" estão permitindo que os designers adicionem animação e interatividade a jornais e revistas digitais. Nesse contexto o artigo apresenta um projeto editorial que aproxima as revistas sociais e as publicações de Moda, com a intenção de criar uma nova plataforma de comunicação e compartilhamento de informação. Primeiramente tem como motivações a diminuição das vendas de revistas impressas, o excesso de conteúdo nas mídias sociais digitais e a procura por conteúdo direcionado. 
O conceito principal é o desenvolvimento de uma "revista social digital", onde a integração de ilustração, textos, fotografias e vídeos estará de acordo com o quarto paradigma da imagem definido por Lucia Santaella.

Com o objetivo de atender o usuário nas suas necessidades práticas e estéticas, algumas referências foram pesquisadas para que a linguagem visual estivesse de acordo com o que já estavam acostumados a consumir nas antigas publicações. Além de revistas impressas, foram também analisados os sites da Numéro, Vanity Fair, Vogue, Harper's Bazaar, e também as lojas online de marcas de roupa de destaque, como Chanel, Fendi, Dolce e Gabbana e Dior. Para atender as necessidades práticas discutiu-se o funcionamento dos sites Pinterest e Flipboard.

O nome escolhido foi Miamag, união do pronome possessivo italiano mia e o substantivo inglês mag (magazine), formando "minha revista", no sentido de criar uma publicação realmente personalizada ao usuário. A tipografia usada no logotipo e nos títulos dos artigos é a Bodoni Bold, muito recorrente nos meios de comunicação de Moda. Para todos os outros textos foi escolhida a tipografia da família Helvetica por ser de fácil leitura nas plataformas digitais, não ser serifada e ter hastes simples e retas. A cor do logotipo e de alguns ícones é a Pantone Ultra Violet 18-3838 (\#5F4B8B), definida como a cor do ano de 2018. Esta cor sofrerá mudança a cada ano, adequando-se às tendências mundiais. Na cartela de cores também encontram-se o branco (\#FFFFFF) e o preto (\#000000).

Figura 8 - Logotipo Miamag.

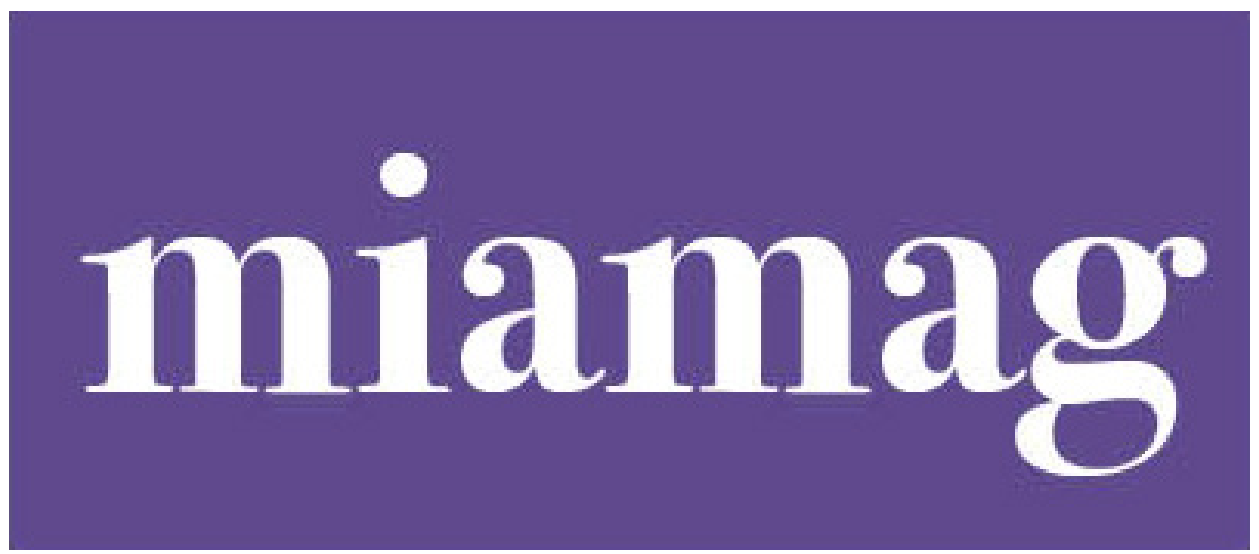

Fonte: Os autores (2018).

Como os modelos da arquitetura, as grades são conjuntos invisíveis de diretrizes, ou sistemas de ordem, que ajudam o designer a determinar a colocação e o uso do texto, imagens e outros elementos de design, como o espaço em branco, margens e fólios, ajudando a dar continuidade enquanto ainda permite a variedade em layout. [...] Quando uma publicação tem um design particularmente fluido, a 
grade atua como uma âncora ou ponto de referência, um ponto de partida que fixa toda a estrutura. (CALDWELL; ZAPATERRA, 2014, p. 155).

Figura 9 - Logotipo Miamag reduzido para perfil das mídias sociais.

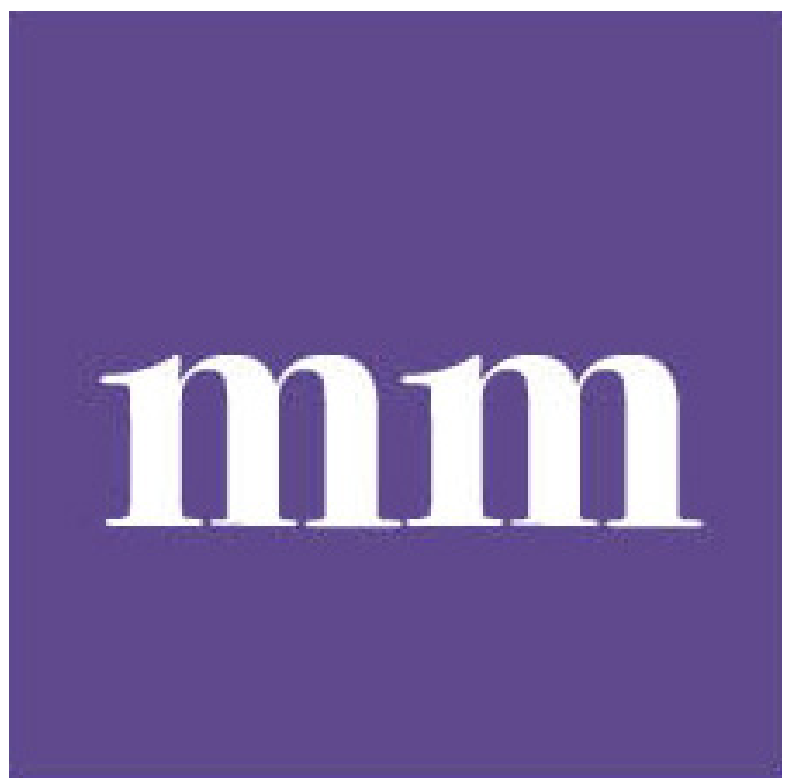

Fonte: Os autores, 2018.

O grid (grade) foi desenhado a partir do MacBook Pro 15 Retina com dimensões de 2280 px de comprimento por 1800 px de largura. As bordas são de 100 px, há doze colunas de 175 px com espaço de 50 px entre elas e linhas horizontais em 150 px, 240 px, 350 px e 525 px.

Figura 10 - Grid do site Miamag.

\begin{tabular}{|l|l|l|l|l|l|l|l|l|l|l|l|l|l|l|l|l|}
\hline & & & & & & & & & & & & & & & & \\
\hline
\end{tabular}

Fonte: Os autores (2018). 
O crescimento da internet mudou completamente a forma como as pessoas consomem informação. A quarta revolução comunicativa, ainda em curso, é caracterizada pela difícil separação entre o emissor e receptor de qualquer mensagem. Sustentada pela era computacional, rompe com o processo de comunicação tradicional, onde o emissor produz as informações e o receptor as recebe. Desta forma, o receptor passa também a emitir os dados em rede e em todas as mídias digitais, e participa ativamente de um processo colaborativo de distribuição de mensagem a um público ilimitado. Se antes o leitor era apenas um receptor de informação através das revistas impressas, hoje também ele tornou-se um emissor e comunicador quando participa e está envolvido nas plataformas digitais. As mídias sociais permitem que este "leitor" seja também um editor das publicações, mostrando a sua visão sobre determinados assuntos de seu interesse.

A Miamag é uma revista personalizada, uma plataforma digital de criação e compartilhamento de conteúdo de Moda. Ela permite que o usuário seja o editor de seus próprios artigos. Funcionando como uma mídia social, também permite acompanhar os editores favoritos, arquivar em seções específicas cada publicação e pesquisar os assuntos mais interessantes no motor de busca. Para que a revista aceite os artigos para publicação, eles devem acompanhar ao menos uma fotografia ou ilustração, a língua em que foi escrito selecionada e também um limite de caracteres dependendo do assunto. Somente depois da análise poderá ser compartilhado e aparecerá na seção Meus Artigos.

Figura 11 - Tela de registro.

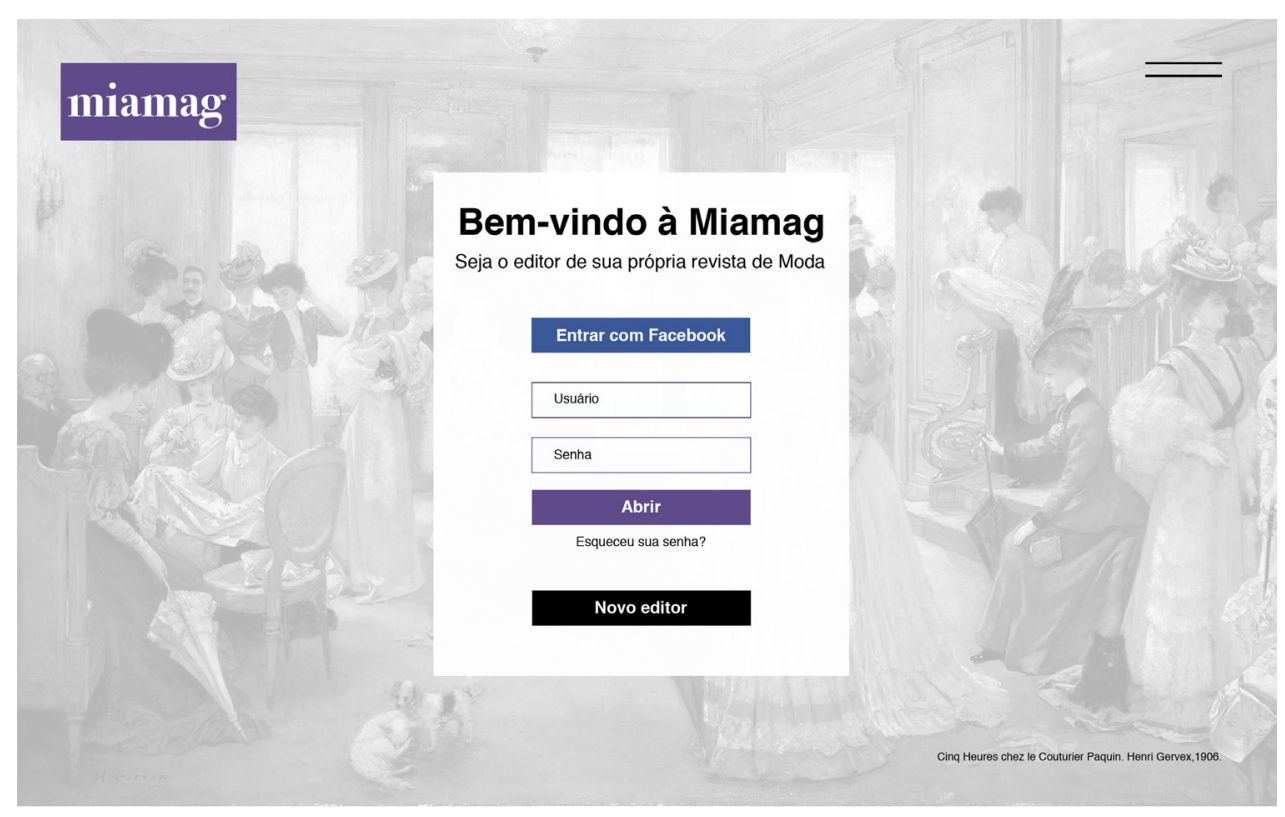

Fonte: Os autores (2018).

Para a visualização do protótipo do site, o link é https://invis.io/3CLCN1EU4TB. Ali encontram-se todas as telas. Na primeira tela pode-se fazer o registro do novo editor, entrar com as informações do Facebook ou com o usuário e a senha já registrados. Na barra lateral superior 
direita encontram-se a explicação do funcionamento da plataforma, política de privacidade, dúvidas frequentes, contatos, configurações e artigos em análise. No cadastro do novo editor são necessárias as seguintes informações: nome e sobrenome, foto de perfil, data de nascimento, línguas que escreve, uma pequena descrição sobre atuação profissional, formação, cursos e experiências.

Logo o site abrirá a página dos Artigos Recentes, as últimas publicações da revista que estão de acordo com as últimas pesquisas e preferências do usuário. Pode-se pesquisar também por temas, como: tendências, fotografia, beleza, desfiles, ilustração, história, entre outras. Ao clicar em um artigo, aparecerá no topo da página o seu respectivo editor e uma breve descrição sobre ele. Também há a opção de adicioná-lo aos seus editores favoritos, bem como salvar a publicação em uma seção da Minha Revista.

A página Criar Publicação é onde o editor criará seus artigos. É necessário preencher as seguintes lacunas: título, data, palavras-chave, língua em que foi escrito, texto e imagens. Ao enviar para a publicação, os editores responsáveis pela Miamag farão a análise e quando for aprovado poderá aparecer nas últimas publicações e também na página de artigos do usuário.

Ao acessar Minha Revista, os artigos podem ser ordenados por seções, títulos, data decrescente ou crescente. Na tela do protótipo está ordenado por seções: calçados, capas de revista, desenho de Moda, estamparia, e muitos outros. Na tela Meu Perfil encontra-se os editores favoritos e os artigos publicados pelo usuário, organizados por data.

Caldwell e Zapaterra (2014) afirmam que quando uma reportagem não possui registro fotográfico ou exige um entendimento mais conceitual, a ilustração é uma boa estratégia para editores de arte expressarem um sentimento mais aprofundado e abstrato do que se fala no texto. Para o mesmo projeto desenvolveu-se um editorial fotográfico que retratasse os três paradigmas unidos (ilustração, texto, fotografia e processos matemáticos de geração de imagem) formando o quarto. As ilustrações de penas foram feitas com técnicas de marcadores e o papel de base foi o Canson ${ }^{\circledR} X L^{\circledR}$ Marker com espessura de $70 \mathrm{~g} / \mathrm{m}^{2}$. O texto que aparece ao fundo é uma das páginas da Revista La Nouvelle Mode, do século XIX. Fotografou-se com a câmera Canon T6, lentes de 50 mm, ISO 100, abertura do diafragma f6,3 e a velocidade do obturador de 1/160s. Afastou-se a modelo do fundo branco para que ele ficasse mais acinzentado nas fotografias. A pós-produção foi feita no Adobe Photoshop CC unindo os três tipos de linguagem. 
Figura 12 - Página do perfil do editor e respectivos artigos.

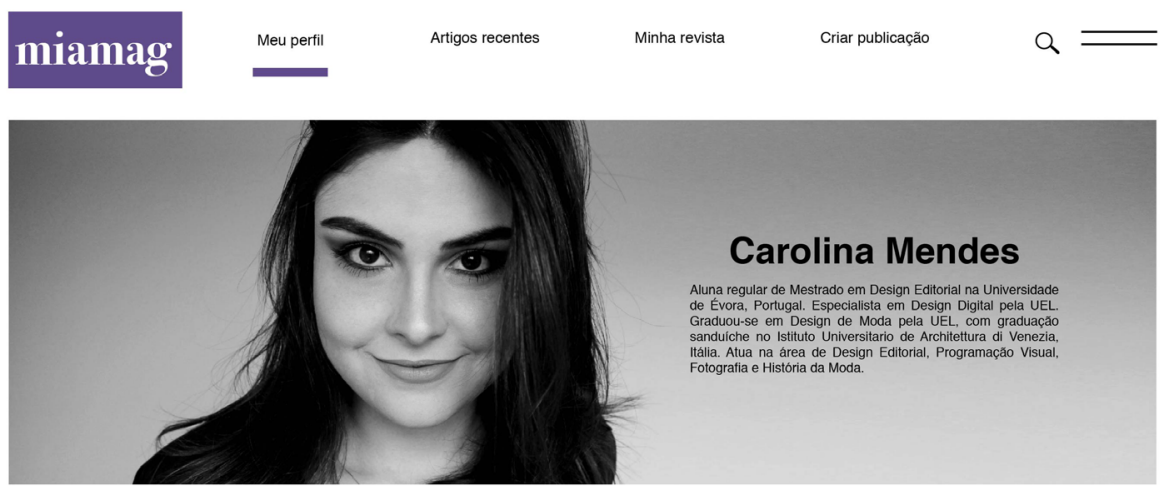

Editores favoritos

Meus artigos

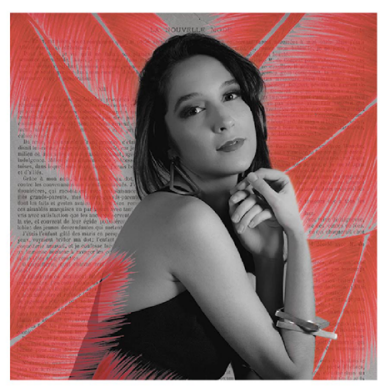

0 quarto paradigma da imagem de Moda

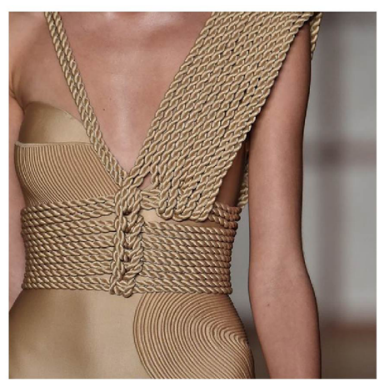

Design e artesanato

13

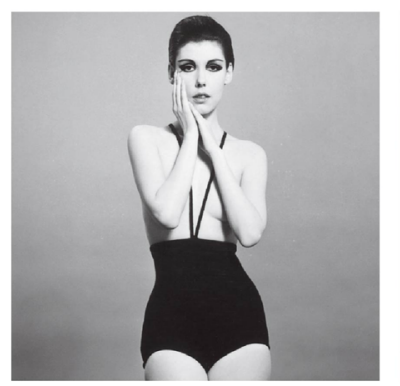

História do Biquíni

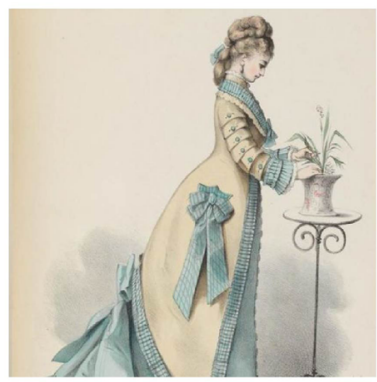

10 Fashion Plates

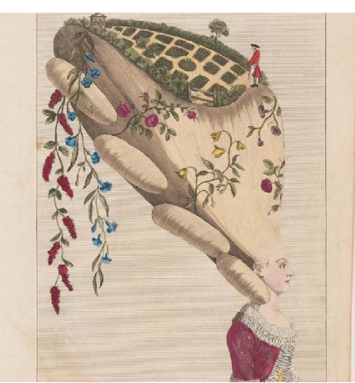

Caricaturas de Moda 11
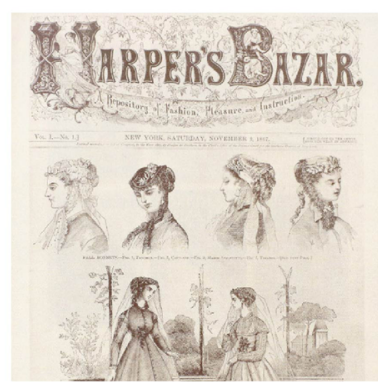

09 Harpers Bazaar 1867

08

Fonte: Os autores (2018). 
GOMES, Rogério Zanetti; ROBERTO, Carolina Mendes Pereira

Figura 13 - Página Minha Revista.

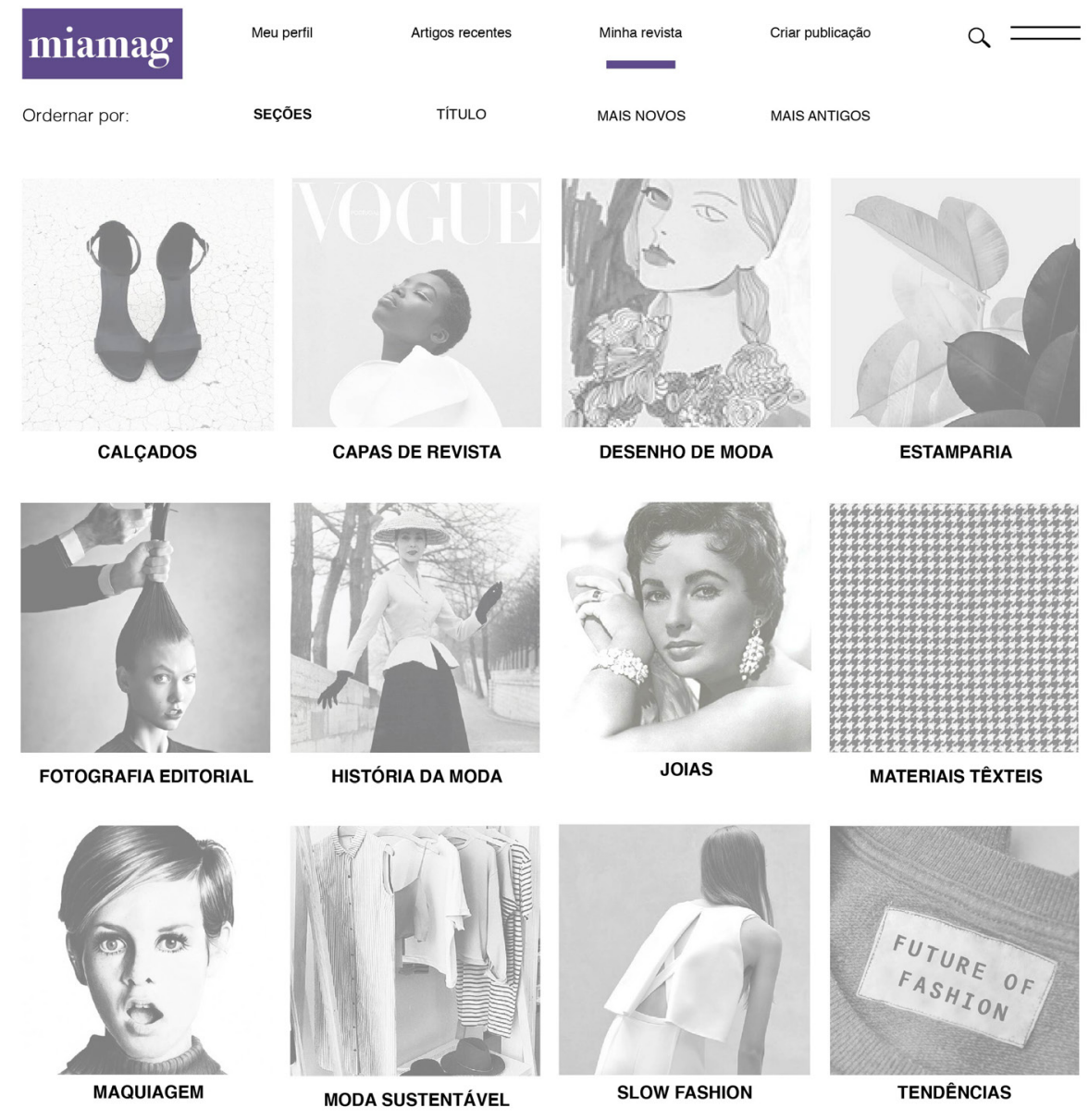

Fonte: Os autores (2018).

Figura 14 - Editorial de Moda.

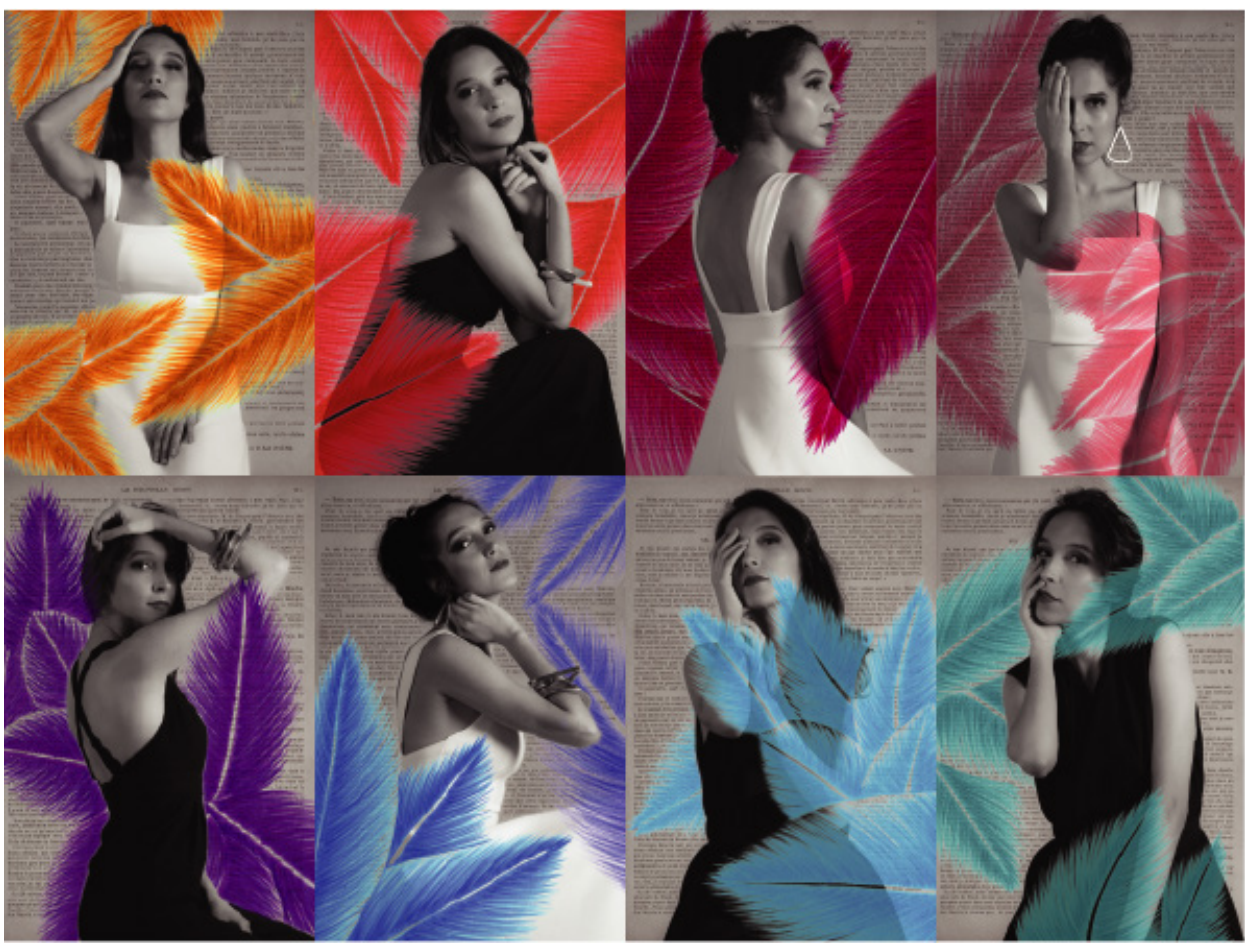

Fonte: Os autores (2018). 


\section{CONSIDERAC̣ÕES FINAIS}

O trabalho faz a distinção entre os três paradigmas das imagens, e como se dá a transição entre eles, relacionando-os aos meios de comunicação impressos e digitais da Moda. Da mesma forma, prevê a aplicação do quarto paradigma da imagem aos meios de comunicação da Moda, onde imagens técnicas estão preparadas para codificar textos em imagens digitais. Propõe um panorama atual das publicações de Moda de maneira que não interrompa o processo de interpretação dos significados abstratos informados. Este processo emancipará os receptores de pensar em conceitos relacionados à escrita e passar a consumir conceitos relacionados à imagem simbólica.

O primeiro paradigma refere-se às imagens que são produzidas artesanalmente, que dependem da habilidade manual de um indivíduo para tornar material o visível, a imaginação visual e o invisível em formas de duas ou três dimensões. No universo da Moda, este paradigma é encontrado nas bonecas que viajavam por toda a Europa com a réplica das roupas usadas por pessoas da alta sociedade francesa, nos Costume Plates e Fashion Plates, primeiras publicações acompanhadas de ilustração e posteriormente textos.

O segundo paradigma é caracterizado pelas imagens que dependem de uma máquina de registro e da presença de objetos reais preexistentes. A imagem é o resultado do rastro luminoso de um objeto sobre um suporte químico ou eletromagnético. No processo de divulgação da Moda é encontrado nas primeiras revistas americanas que utilizaram a fotografia analógica para apresentar às leitoras imagens reais de modelos, celebridades, desfiles, e como aquelas roupas poderiam ser adaptadas ao seu cotidiano.

O terceiro diz respeito às imagens sintéticas ou infográficas inteiramente calculadas por computação e que são independentes de um objeto existente. Dependem da linguagem informática, um programa e uma tela. Com o avanço da tecnologia a partir dos anos 90, foi possível aplicar este paradigma nas publicações de Moda. Revistas digitais, sites, aplicativos e mídias sociais passaram a permitir o compartilhamento de conteúdo, tornando o leitor receptor de mensagens em emissor.

O quarto paradigma da imagem é o resultado da união entre os três paradigmas anteriores, ou seja, o hibridismo entre mídias e linguagens. Os autores propõem um novo meio de divulgação da Moda que corresponda às características deste tipo de imagem por meio de técnicas de design editorial, programação visual e fotografia. O excesso de conteúdo nas mídias sociais digitais, a diminuição das vendas de revistas de Moda impressas e a procura por conteúdo direcionado são motivações para a interação entre diversos tipos de imagem, e consequentemente o desenvolvimento de uma nova mídia de criação e compartilhamento de informação. "Os designers treinados 
para a impressão tiveram de se atualizar, aprender e codificar e adaptar suas habilidades às mídias digitais interativas. Os "nativos digitais" mais jovens não encontraram nenhum problema em projetar para diferentes plataformas." (CALDWELL; ZAPATERRA, 2014, p. 59). O design editorial deve acompanhar as mudanças socioeconômicas e tecnológicas para que nas diferentes mídias, sejam elas impressas ou digitais, possa se adaptar e continuar existindo.

A próxima geração de talentos em publicação ainda terá de contar as histórias que precisam ser contadas, mas vai usar a sua facilidade natural com as mídias sociais como parte de suas ferramentas de saída. Atualmente, é um mito imaginar que existe uma única "próxima grande coisa" que substituirá a mídia impressa. Em vez disso, editores e designers estão contando histórias em todas as mídias que os leitores possam consumir. (CALDWELL; ZAPATERRA, 2014, p. 233). 


\section{REFERÊNCIAS}

BATCHELOR, Jennie. The Lady's magazine: a special guest blog by Jennie Batchelor. 2016. Disponível em: https://www.amdigital.co.uk/about/blog/ item/ladys-magazine. Acesso em 5 ago. 2018.

CALDWELL, Cath; ZAPATERRA, Yolanda. Design editorial: jornais e revistas/ mídia impressa e digital. São Paulo: Gustavo Gilli, 2014.

FASHION. Vogue. Disponível em: https://www.vogue.com/?us_site=y. Acesso em: 5 ago. 2018.

FLUSSER, Vilém. Filosofia da caixa preta. São Paulo: Hucitec, 1985.

HUTCHINGS, Lucy. Style file: Cindy Crawford. Vogue, Nova York, 2009. Disponível em: https://www.vogue.co.uk/gallery/style-file-cindy-crawford. Acesso em: 5 ago. 2018.

MIRANDA, Eugenia. From the archives: tem vogue "firsts". Vogue, Nova York, 2012. Disponível em: https://www.vogue.com/article/from-the-archives-tenvogue-firsts. Acesso em: 5 ago. 2018.

MOOALEM, Stephen. 1540 years of harper's bazar. 2017. Disponível em: https://www.harpersbazaararabia.com/people/culture/150-years-of-harper'sbazaar. Acesso em: 5 ago. 2018.

SANTAELLA, Lucia. Comunicação ubíqua: repercussões na cultura e na educação. São Paulo: Paulus, 2013.

Projética, Londrina, v.10, n.3, p. 175-196, jul./dez. 2019 
SANTAELLA, Lucia; NOTH, Winfried. Imagem: cognição, semiótica, mídia. São Paulo: lluminuras, 1997.

VOGUE. Vogue international. 2018. Instagram: @vogue. Disponível em: <https://www.instagram.com/vogue/>. Acesso em ago. 2018.

YAEGER, Lynn. Saluting baron Adolph de Meyer, vogue's first staff photographer. Vogue, Nova York, 2015. Disponível em: https://www.vogue. com/article/adolph-de-meyer-birthday-vogue-photographer. Acesso em: 5 ago. 2018.

Data de submissão: 2018-12-17

Data de aceite: 2019-02-18 